\title{
Sporulation of Fusarium solani f. sp. glycines, Causal Agent of Sudden Death Syndrome, on Soybeans in the Midwestern and Southern United States
}

\author{
K. W. Roy, Professor, Department of Entomology and Plant Pathology, Mississippi State University, Mississippi \\ State 39762
}

\begin{abstract}
Roy, K. W. 1997. Sporulation of Fusarium solani f. sp. glycines, causal agent of sudden death syndrome, on soybeans in the midwestern and southern United States. Plant Dis. 81:566-569.

Production of macroconidia by the causal agent of sudden death syndrome, Fusarium solani $\mathrm{f}$. sp. glycines, occurred on lower stems and roots of soybean plants symptomatic for the disease in Illinois, Indiana, Kentucky, Mississippi, and Tennessee. Most of the sporulation was light to dark blue to blue-green in color. Microscopically $(15 \times)$ visible sporulation occurred on plants in 26 , and macroscopically visible sporulation occurred on plants in 15 , of 32 fields inspected. In some fields, the incidence of plants with microscopically visible sporulation was as high as $70 \%$, and the incidence of plants with macroscopically visible sporulation reached $50 \%$. Sporulation varied from pinpoint microscopic areas to macroscopically visible masses 4 to $6 \mathrm{~cm}^{2}$ or larger. Areas of microscopically visible sporulation occurred on lower stems and roots within $2.5 \mathrm{~cm}$ above and below the soil line on about $50 \%$ of the plants, and areas of macroscopically visible sporulation occurred within the same region on about $60 \%$ of the plants. Both microscopic and macroscopic sporulation also occurred on taproots as far as $10 \mathrm{~cm}$ or more below the soil line. Severe foliar symptoms and root decay were associated with a greater incidence of plants with sporulation. The occurrence of sporulation should help distinguish sudden death syndrome from other diseases of like foliar symptomatology and help confirm its diagnosis. It is presumed from the results that sporulation eventually contributes to the inoculum density of $F$. solani f. sp. glycines in soybean fields.
\end{abstract}

Sudden death syndrome (SDS) of soybean (Glycine max (L.) Merr.), a relatively new disease, occurs in Alabama, Arkansas, Illinois, Indiana, Iowa, Kansas, Kentucky, Mississippi, Missouri, and Tennessee $(11,12,16,19,28-31,34,37,41,43)$. A form of Fusarium solani (Mart.) Sacc., distinguished as form A (FSA), is the causal agent of SDS $(19,25,27-30,34,36)$. The name $F$. solani f. sp. phaseoli type A has also been used in reference to the SDS causal fungus $(6,14,23)$. Some researchers have suggested that SDS-inciting isolates of $F$. solani are $F$. solani f. sp. phaseoli (24) or that they represent a subgroup within $F$. solani $\mathrm{f}$. sp. phaseoli or possibly a separate form species (1). Recently, FSA was designated $F$. solani (Mart.) Sacc. f.

Corresponding author: K. W. Roy

E-mail: sunil@ra.msstate.edu

Published with the approval of the Director, Mississippi Agricultural and Forestry Experiment Station, as Journal Series Paper No. J-8842.

Supported in part by funds provided by the American Soybean Association and the Mississippi Soybean Promotion Board.

Accepted for publication 6 March 1997.

Publication no. D-1997-0423-08R

(C) 1997 The American Phytopathological Society sp. glycines form. nov. on the basis of physiological specialization, its distinction from $F$. solani form B and other strains and formae speciales of $F$. solani, including $F$. solani f. sp. phaseoli (Burkholder) W.C. Snyder \& H.N. Hans., and further morphological and cultural characterization (25).

The major symptoms of SDS include root rot, crown necrosis, vascular discoloration of roots and stems, interveinal chlorosis and necrosis of leaves, premature defoliation of leaflets (resulting in bare petioles), and pod abortion (11,12,19,28, $30,31,34)$. The disease is often associated with irrigation $(12,19,28,30)$ and persistently high soil moisture $(12,17,19,28$, 30,34). Hot, dry conditions appear to arrest disease development $(12,17,19)$. SDS has been particularly prevalent in western Kentucky, southeastern Illinois, and southwestern Indiana, near the Mississippi and Ohio rivers $(11,26)$.

Because SDS is a relatively new disease, data on certain aspects of the disease cycle, including reproduction of the pathogen on diseased plants in the field, are limited. Although it was noted that $F$. solani f. sp. glycines produced macroconidia on lower stems and roots of SDS-symptomatic plants (19), this was neither quantified nor described in any detail. A better understanding of this fundamental aspect of the disease cycle is needed because it may be relevant with respect to the inoculum density of $F$. solani f. sp. glycines in the soil. In addition, the occurrence of sporulation may have practical application in the diagnosis of SDS and in the isolation of $F$. solani f. sp. glycines.

Field observations by the author in Mississippi and elsewhere suggested that occurrence of $F$. solani f. sp. glycines sporulation on roots of SDS-symptomatic plants was more common than generally expected and might be influenced by symptom severity. An investigation to confirm these observations was initiated during SDS disease surveys in the midwestern and southern United States. The frequency and geographic distribution of sporulation, and its relation to SDS severity, the SDS disease cycle, and diagnosis of SDS, are reported.

\section{MATERIALS AND METHODS}

Incidence, geographic distribution, and characteristics of sporulation on soybean roots. In August of 1992 and 1994, SDS-symptomatic plants were sampled from 18 and 14 soybean fields, respectively, in Arkansas, Kentucky, Illinois, Indiana, Mississippi, and Tennessee (Table 1). Growth stage (8) of soybean plants at the time of sampling ranged from R3 to slightly beyond R7, but most plants were in the R5 to R6 stage. A random sample of 10 plants symptomatic for SDS was collected from each field. An "X" sampling pattern, with each arm extending approximately $30 \mathrm{~m}$, was used to collect samples. The area on the stem-root transition zone corresponding to the soil line was marked, individual plant specimens were labeled, and plants were uprooted. Since the length of taproots varied within and among samples, examination of each root was limited to a $12.5-\mathrm{cm}$ portion below the soil line. The uprooted plants were severed about 7 $\mathrm{cm}$ above the soil line with pruning shears, the upper portion was discarded, and the incidence of macroscopically visible sporulation (macroconidia) on the 7-cm stem portions and the $12.5-\mathrm{cm}$ root portions was recorded.

To prevent sporulation during transit, the samples were placed in resealable plastic bags that were stored open and upright over ice in a cooler $\left(4\right.$ to $\left.8^{\circ} \mathrm{C}\right)$ for less than $24 \mathrm{~h}$, after which they were quickly air- 
dried under a fume hood prior to further examination. Specimens then were examined to distinguish between macroscopically visible and microscopically visible sporulation. For microscopic examination, the entire surface area of the 7-cm stem portions, the $12.5-\mathrm{cm}$ taproot portions, and the lateral roots was scanned with a stereomicroscope $(15 \times)$. Occurrence of sporulation, the location and distribution of discrete areas of sporulation, and the color of sporulation were recorded for each specimen. Occurrence of sporulation on lateral roots was recorded, but no attempt was made to estimate distribution along the axis because destruction of lateral roots during uprooting resulted in remnants variable in length.

To confirm the identity of $F$. solani $\mathrm{f}$. sp. glycines, sporodochia and conidia from various regions of sporulation were mounted in lactophenol-cotton blue on microscope slides and viewed microscopically. The dimensions of 25 conidia were determined for seven roots, each sampled from a different field in 1994. Single-spore transfers from roots to potato-dextrose agar (PDA) were made for observations on colony characteristics. Cultures were incubated for 14 days at ambient temperatures in the laboratory.

Relationship between SDS severity and incidence of plants with sporulation. In each field, both years, an assessment of SDS severity based on foliar symptoms was recorded for symptomatic plants within the " $X$ " pattern that was used for collecting specimens. Dying plants with bare petioles and leaves with extensive interveinal necrosis were considered indicative of severe disease; plants lacking these symptoms but exhibiting leaves with interveinal chlorosis and little or no necrosis were considered indicative of less severe disease. Based on the proportion of plants falling into each disease severity category, fields were ranked as to disease severity. Eighteen fields were ranked in 1992 and 14 in 1994. The lowest ranking (least severe SDS) was 1 in both years, and the highest (most severe SDS) was 18 in 1992 and 14 in 1994. In 1992, the incidence of microscopic and macroscopic sporulation on plants in fields ranked 1 to 9 in SDS severity was compared with that in fields ranked 10 to 18. Similarly, in 1994, the incidence of sporulation in fields ranked 1 to 7 was compared with that in fields ranked 8 to 14 . Each year, the rankings were also used to calculate Spearman rank-order correlations (39) between foliar disease severity and incidence of plants with sporulation.

In 1994, in each of four fields in Illinois (Equality, Eldorado, Harrisburg, and Ridgeway), the comparative incidence of plants with macroscopic sporulation was determined for 20 SDS-symptomatic plants exhibiting root decay and an equal number of SDS-symptomatic plants lacking root decay. Plants with decayed roots were easily selected from among other SDSsymptomatic plants because they were noticeably easier to uproot. Such plants had severe foliar symptoms, i.e., bare petioles and extensive interveinal necrosis. Plants lacking any discernible root decay typically were uprooted with greater difficulty, did not exhibit defoliation, and had extensive interveinal chlorosis and mild interveinal necrosis. Data from the four individual Illinois fields were considered replications. The same type of comparison was made in Starkville, Mississippi, at the Mississippi State University Plant Science Research Center. Methodology used in the four Illinois fields was also used in Starkville, with the exception that the two sets of plant samples were collected from four replicate rows of cv. Asgrow 4715. This cultivar, which is susceptible to SDS (25), was planted in a randomized complete block design on 28 April 1994, in rows $8 \mathrm{~m}$ long and $1 \mathrm{~m}$ apart. The field was irrigated by flooding twice during the postflowering period.

\section{RESULTS \\ Incidence, geographic distribution, and characteristics of sporulation on}

Table 1. Incidence of sporulation by Fusarium solani f. sp. glycines on soybean plants symptomatic for sudden death syndrome in six midwestern and southern states in 1992 and 1994

\begin{tabular}{|c|c|c|c|c|c|c|c|c|}
\hline \multirow[b]{3}{*}{ Year } & \multirow[b]{3}{*}{ State } & \multirow[b]{3}{*}{$\begin{array}{c}\text { Fields } \\
\text { sampled }\end{array}$} & \multicolumn{6}{|c|}{ Plants with sporulation ${ }^{a}$} \\
\hline & & & \multicolumn{3}{|c|}{ Microscopic (15x) } & \multicolumn{3}{|c|}{ Macroscopic } \\
\hline & & & $\begin{array}{c}\text { Fields } \\
\text { (no.) }\end{array}$ & $\begin{array}{l}\text { Avg. } \\
(\%)\end{array}$ & $\underset{(\%)}{\operatorname{Max} .}$ & $\begin{array}{c}\text { Fields } \\
\text { (no.) }\end{array}$ & $\begin{array}{l}\text { Avg. } \\
(\%)\end{array}$ & $\underset{(\%)}{\operatorname{Max} .}$ \\
\hline \multirow[t]{5}{*}{1992} & Tennessee & 1 & 1 & 40 & 40 & 0 & 0 & 0 \\
\hline & Kentucky & 3 & 3 & 37 & 60 & 1 & 7 & 20 \\
\hline & Illinois & 8 & 6 & 28 & 70 & 5 & 10 & 30 \\
\hline & Indiana & 5 & 3 & 12 & 30 & 1 & 2 & 10 \\
\hline & Arkansas & 1 & 0 & 0 & 0 & 0 & 0 & 0 \\
\hline \multirow[t]{4}{*}{1994} & Kentucky & 3 & 3 & 47 & 60 & 1 & 17 & 50 \\
\hline & Indiana & 2 & 2 & 45 & 60 & 1 & 15 & 30 \\
\hline & Illinois & 6 & 5 & 35 & 70 & 4 & 13 & 30 \\
\hline & Mississippi & 3 & 3 & 30 & 70 & 2 & 10 & 20 \\
\hline
\end{tabular}

a Percentage of plants with sporulation refers to the frequency of occurrence of sporulation on any portion of the lower stem (a $7-\mathrm{cm}$ section immediately above the soil line) or the root (a $12.5-\mathrm{cm}$ section immediately below the soil line).

soybean plants. In 1992, microscopic sporulation occurred on lower stems and roots of plants in 13 of 18 sampled fields, and macroscopic sporulation occurred on plants in seven of 18 fields (Table 1). The ranges in average and maximum frequencies of microscopic sporulation were 0 to $40 \%$ and 0 to $70 \%$, respectively. The ranges in average and maximum frequencies of macroscopic sporulation were 0 to $10 \%$ and 0 to $30 \%$, respectively. In 1994 , microscopic sporulation occurred in 13 of 14 sampled fields. Macroscopic sporulation occurred on plants in eight of these fields. The ranges in average and maximum frequencies of microscopic sporulation were 30 to $47 \%$ and 60 to $70 \%$, respectively. The ranges in average and maximum frequencies of macroscopic sporulation were 10 to $17 \%$ and 20 to $50 \%$, respectively.

The color of sporulation ranged from light (Fig. 1) to dark blue to blue-green. Only macroconidia were found in the regions of sporulation observed. Macroconidia ranged in size from 42 to $50 \mu \mathrm{m}$ long by 4 to $5 \mu \mathrm{m}$ wide. They occurred in distinct sporodochia, and the sporodochia aggregated into relatively large, macroscopic masses of sporulation, or into relatively small and microscopic, pulvinate tufts. On PDA, colony growth was relatively slow and sporodochia with blue to

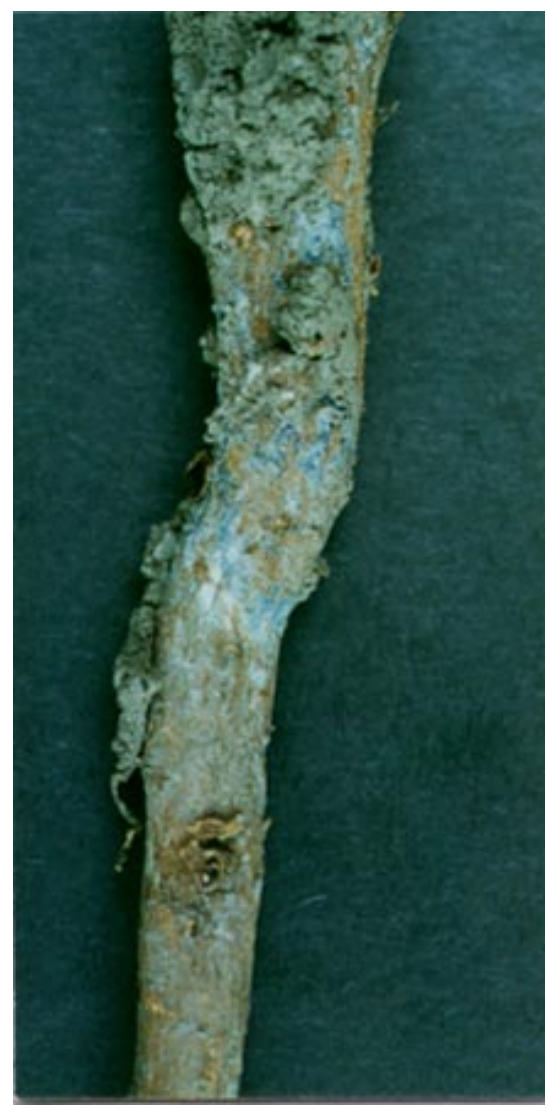

Fig. 1. Varying amounts of sporulation (blue areas) by Fusarium solani f. sp. glycines on different portions of a soybean taproot from a sudden death syndrome-symptomatic plant. 
blue-green spore masses were produced.

Of the roots exhibiting sporulation, only about $5 \%$ of the sporulation occurred on lateral roots, usually within $2.5 \mathrm{~cm}$ of the juncture with the taproot, whereas about 95\% of the sporulation occurred on taproots at various locations along the vertical axis. Of those plants with sporulation, approximately $51 \%$ of the microscopic sporulation occurred on the lower stem and upper taproot within $2.5 \mathrm{~cm}$ above and below the soil line, $42 \%$ on the taproot within 2.5 to $7.5 \mathrm{~cm}$ below the soil line, and $7 \%$ on the taproot within 7.5 to 12.5 $\mathrm{cm}$ below the soil line. Approximately $60 \%$ of the macroscopic sporulation occurred on the lower stem and upper taproot within $2.5 \mathrm{~cm}$ above and below the soil line, $38 \%$ on the taproot within 2.5 to 7.5 $\mathrm{cm}$ below the soil line, and $2 \%$ on the taproot within 7.5 to $12.5 \mathrm{~cm}$ below the soil line (percentages were obtained by averaging across fields and years). The size of individual areas of sporulation varied from macroscopic areas about 4 to $6 \mathrm{~cm}^{2}$ to pinpoint areas less than $1 \mathrm{~mm}^{2}$. Pinpoint areas often occurred in a scattered pattern spanning $2.5 \mathrm{~cm}$ or more of the taproot axis.

Relationship between SDS severity and incidence of plants with sporulation. In 1992 and 1994, both microscopic and macroscopic sporulation occurred in greater frequency on lower stems and roots of plants from fields ranked highest in severity of SDS foliar symptoms (Table 2). The frequency of plants with microscopic sporulation was more than twofold greater, and the frequency of plants with macroscopic sporulation was more than eight times greater, in fields ranked highest in disease severity. Correlations between the incidence of plants with microscopic sporulation and severity of foliar symptoms were 0.55 and 0.76 in 1992 and 1994 , respectively $(P \leq 0.05)$. Correlations between the incidence of plants with macroscopic sporulation and severity of foliar symptoms were 0.51 and 0.71 in 1992 and 1994, respectively $(P \leq 0.05)$.

The average incidence of macroscopic sporulation on decayed roots from the four Illinois fields was $38 \%$, and that on decayed roots from the Starkville field was
$21 \%$. Sporulation was not observed on asymptomatic roots in either test.

\section{DISCUSSION}

The color of the sporulation on SDSsymptomatic plants, absence of microconidia, characteristics of sporodochia and macroconidia from roots, and characteristics of colonies on PDA agreed with previous descriptions of $F$. solani f. sp. glycines $(25,28-30,34,36)$. F. solani form B $(25,28-$ 30 ), the $F$. solani implicated in Essex syndrome (10), and $F$. solani f. sp. pisi (32) also colonize soybean roots, but they possess morphological and/or cultural characteristics $(10,18,28-30,42)$ that distinguish them from $F$. solani $\mathrm{f}$. sp. glycines $(25,28-$ 30). Therefore, it was concluded that the fungus sporulating on soybean roots was $F$. solani f. sp. glycines.

Results indicate that sporulation of $F$. solani f. sp. glycines on lower stems and roots of soybean plants occurs relatively frequently and is geographically widespread. The distribution of sporulation on the vertical axis of the lower stem and taproot closely parallels the spatial distribution of $F$. solani f. sp. glycines in lower stems and taproots. This fungus is rarely isolated from surface-disinfested tissue above the soil line, and it is typically isolated more frequently from the upper than the lower portion of the taproot $(19,28,30)$. The fact that sporulation occurred on root tissue below the soil surface, where there was little or no exposure to light, indicates the need for research on the effect of light on sporulation in the field. The greater frequency of macroscopic sporulation on taproots as compared with lateral roots is probably largely due to the sampling technique. Most of the lateral roots were left in the soil at sampling, and therefore a larger surface area of sampled taproot tissue was available for examination.

Frequency of occurrence of sporulation varied among locations and between years, suggesting environmental and/or biotic influences. There likely are many individual and interacting factors indirectly or directly influencing the incidence and amount of sporulation on plants in the field. Cool to moderate temperatures

Table 2. Relationship between frequency of occurrence of sporulation by Fusarium solani f. sp. glycines on soybean plants and relative severity of foliar symptoms of sudden death syndrome (SDS) in soybean fields in six midwestern and southern states in 1992 and $1994^{\mathrm{a}}$

\begin{tabular}{lccccc}
\hline & \multicolumn{2}{c}{ Relative SDS severity } & & \multicolumn{2}{c}{ Plants with sporulation $(\%)^{\mathbf{c}}$} \\
\cline { 2 - 3 } \cline { 5 - 6 } Year & $\begin{array}{c}\text { Fields ranked } \\
\text { for severity }\end{array}$ & $\begin{array}{c}\text { SDS severity } \\
\text { rankings }^{\mathbf{b}}\end{array}$ & & $\begin{array}{c}\text { Microscopic } \\
(\mathbf{1 5} \times)\end{array}$ & Macroscopic \\
\hline 1992 & 18 & 1 to 9 & & 13 & 1 \\
& 10 & 10 to 18 & & 34 & 12 \\
1994 & 14 & 1 to 7 & & 23 & 3 \\
& & 8 to 14 & 54 & 24 \\
\hline
\end{tabular}

a Arkansas, Illinois, Indiana, Kentucky, Mississippi, and Tennessee.

b 1 = least severe; 18 (1992) or $14(1994)=$ most severe.

${ }^{\mathrm{c}}$ Percentage of plants with sporulation refers to the frequency of occurrence of sporulation on any portion of the lower stem (a $7-\mathrm{cm}$ section immediately above the soil line) or the root (a $12.5-\mathrm{cm}$ section immediately below the soil line).
$(12,33)$, irrigation and persistently high moisture $(17,19,28,30,31)$, the presence of SCN in soil $(19,26,28,30)$, and planting soybeans early or at the recommended time (compared with planting late) (11) favor SDS development and severe infection. Because greater SDS severity, particularly severity of root decay, was shown in the present study to be associated with an increased incidence of plants with sporulation, it is reasonable to assume that these four factors indirectly affect sporulation and contribute to variability in the incidence and degree of sporulation on plants. However, a substantial proportion of severely diseased plants had no detectable sporulation. This points to the involvement of other factors which can directly affect sporulation. The optimum temperature for growth of $F$. solani f. sp. glycines in culture is ca. $25^{\circ} \mathrm{C}(25,33)$; temperatures in excess of $30^{\circ} \mathrm{C}$ inhibit growth and therefore sporulation. Exposure of diseased roots to free-standing water promotes sporulation by $F$. solani f. sp. glycines (K. W. Roy, unpublished). Controlled studies of the effect of temperature and other variables on sporulation are needed.

Sporulation of soilborne fusaria commonly occurs on diseased host roots and lower stems above the soil line $(3,4,40)$. When macroconidia of $F$. solani f. sp. phaseoli that are produced on hypocotyls of diseased bean plants are washed into the soil by rain, they quickly convert to chlamydospores. This is considered to increase substantially the inoculum density of $F$. solani f. sp. phaseoli in the soil $(4,7,18,20,21,40)$. Macroconidia of F. solani f. sp. glycines also convert to chlamydospores (19), and it is presumed from results of the present study that sporulation by $F$. solani f. sp. glycines eventually contributes to the inoculum in soybean fields. This would be compatible with results of Rupe and Becton, who found that inoculum density of $F$. solani f. sp. glycines increased as soybean harvest time approached (35; J. C. Rupe, personal communication). Sporulation on plants would appear to be particularly relevant in no-till fields, since the likelihood of sporulation would probably be greater on decayed roots which persist beyond harvest time and into the next growing season.

Macroconidia produced in sporodochia on diseased hosts of soilborne fusaria can be dispersed onto the soil surface by splashing rain $(9,13)$. They also may become airborne in dust during harvesting $(4,9,13,15)$ and thereby infest harvested seeds $(5,22)$. Possibly through similar circumstances, rain-splashed macroconidia of F. solani f. sp. glycines could be dispersed within a field by runoff water; if they became airborne during soybean harvesting, they could infest seeds. Although $F$. solani f. sp. glycines has not been found to be internally seedborne (19), dissemination of this fungus could occur via infested seeds. 
Signs are sometimes decisive in disease diagnosis, and they afford an opportunity for direct isolation of fungal pathogens. The relatively high frequency and geographically widespread occurrence of $F$. solani f. sp. glycines sporulation on plants suggest an application in SDS diagnosis and in the acquisition of $F$. solani $\mathrm{f}$. sp. glycines isolates for study. With regards to diagnosis, it would be particularly helpful in regions of soybean production where diseases of like foliar symptomatology, such as stem canker, brown stem rot, and red crown rot $(2,38)$, occur. In such situations, the presence of $F$. solani f. sp. glycines sporulation on plants, combined with the presence of at least some plants with interveinal chlorosis and/or necrosis, would help distinguish SDS from other diseases and confirm its diagnosis. Attempts to isolate $F$. solani $\mathrm{f}$. sp. glycines from diseased lower stems and roots by the conventional method, i.e., surface-disinfesting and culturing tissue on an agar medium, can often be problematic and inefficient, for a variety of reasons. Under most circumstances, it is less timeconsuming and more efficient to obtain isolates from diseased plants by direct transfer of $F$. solani $\mathrm{f}$. sp. glycines macroconidia from the macroscopic sporulation on lower stems or roots to an agar medium (29; K. W. Roy, unpublished).

\section{LITERATURE CITED}

1. Achenbach, L. A., Patrick, J., and Gray, L. 1996. Use of RAPD markers as a diagnostic tool for the identification of Fusarium solani isolates that cause soybean sudden death syndrome. Plant Dis. 80:1228-1232.

2. Athow, K. L. 1987. Fungal diseases. Pages 687-727 in: Soybeans: Improvement, Production and Uses. J. R. Wilcox, ed. Am. Soc. Agron., Madison, WI.

3. Booth, C. 1971. The Genus Fusarium. Commonw. Mycol. Inst./Assoc. Appl. Biol., Kew, Surrey, England.

4. Burgess, L. W. 1981. General ecology of the Fusaria. Pages 225-235 in: Fusarium: Diseases, Biology, and Taxonomy. P. E. Nelson, T. A. Toussoun, and R. J. Cook, eds. Pennsylvania State University, University Park.

5. Burkholder, W. H. 1919. The dry root-rot of the bean. Cornell Univ. Agric. Exp. Stn. Mem. 26:999-1033.

6. Chang, S. J. C., Doubler, T. W., Kilo, V., Suttner, R., Klein, J., Schmidt, M. E., Gibson, P. T., and Lightfoot, D. A. 1996. Two additional loci underlying durable field resistance to soybean sudden death syndrome (SDS). Crop Sci. 36:1684-1688.

7. Christou, T., and Snyder, W. C. 1962. Penetration and host-parasite relationships of Fusarium solani f. phaseoli in the bean plant. Phytopathology 52:219-226.

8. Fehr, W. R., Caviness, C. E., Burmood, D. T., and Pennington, J. S. 1971. Stage of development descriptions for soybeans, Glycine $\max ($ L.) Merr. Crop Sci. 11:929-931.

9. Gregory, P. J., Guthrie, E. J., and Bunce, M. E. 1959. Experiments in splash dispersal of fungus spores. J. Gen. Microbiol. 20:328-354.
10. Griffin, G. L. 1990. Importance of Pythium ultimum in a disease syndrome of cv. Essex soybean. Can. J. Plant Pathol. 12:135-140.

11. Hershman, D. E., Hendrix, J. W., Stuckey, R. E., Bachi, P. R., and Henson, G. 1990. Influence of planting date and cultivar on soybean sudden death syndrome in Kentucky. Plant Dis. 74:761-766.

12. Hirrel, M. C. 1987. Sudden death syndrome of soybean: New insights into its development. Am. Seed Trade Assoc., Soybean Res. Conf., 16th. 16:95-104.

13. Hirst, J. M. 1965. The dispersal of soil microorganisms. Pages 69-81 in: Ecology of Soilborne Plant Pathogens. K. F. Baker and W. C. Snyder, eds. University of California, Berkeley.

14. Hnetkovsky, N., Chang, S. J. C., Doubler, T. W., Gibson, P. T., and Lightfoot, D. A. 1996. Genetic mapping of loci underlying field resistance to soybean sudden death syndrome (SDS). Crop Sci. 36:393-400.

15. Horst, R. K., Nelson, P. E., and Toussoun, T. A. 1970. Aerobiology of Fusarium spp. associated with stem rot of Dianthus caryophyllus. (Abstr.) Phytopathology 60:1296.

16. Jardine, D. J., and Rupe, J. C. 1993. First report of sudden death syndrome of soybeans caused by Fusarium solani in Kansas. Plant Dis. 77:1264.

17. Kiarie, S. K., Gibson, P. T., and Myers, O. 1989. Sudden death syndrome of soybean: Planting date and environmental influences. (Abstr.) Proc. Am. Soc. Agron. 70:101.

18. Kraft, J. M., Burke, D. W., and Haglund, W. A. 1981. Fusarium diseases of bean, peas, and lentils. Pages 142-156 in: Fusarium: Diseases, Biology, and Taxonomy. P. W. Nelson, T. A. Toussoun, and R. J. Cook, eds. Pennsylvania State University, University Park.

19. Melgar, J., Roy, K. W., and Abney, T. S. 1994. Sudden death syndrome of soybean: Etiology, symptomalogy, and effects of irrigation and Heterodera glycines on incidence and severity under field conditions. Can. J. Bot. 72:16471653.

20. Nash, S. M., and Alexander, J. V. 1965. Comparative survival of Fusarium solani f. cucurbitae and F. solani f. phaseoli in soil. Phytopathology 55:963-966.

21. Nash, S. M., Christou, T., and Snyder, W. C. 1961. Existence of Fusarium solani f. sp. phaseoli as chlamydospores in soil. Phytopathology 51:308-312.

22. Nash, S. M., and Snyder, W. C. 1964. Dissemination of the root rot Fusarium with bean seed. Phytopathology 54:880.

23. Njiti, V. N., Suttner, R. J., Gray, L. E., Gibson P. T., and Lightfoot, D. A. 1997. Rate reducing resistance to Fusarium solani f. sp. phaseoli underlies field resistance to soybean sudden death syndrome. Crop Sci. 37:132138.

24. O'Donnell, K. O., and Gray, L. E. 1995. Phylogenetic relationships of the soybean sudden death syndrome pathogen Fusarium solani f. sp. phaseoli inferred from rDNA sequence data and PCR primers for its identification. Mol. Plant-Microbe Interact. 8:709716.

25. Roy, K. W. 1997. Fusarium solani on soybean roots: Nomenclature of the causal agent of sudden death syndrome and identity and relevance of $F$. solani form B. Plant Dis. 81:259266.

26. Roy, K. W., Abney, T. S., and Patel, M. V. 1993. Soybean SDS in the Midwest and South: Disease incidence and association of
Fusarium solani with roots and with cysts of Heterodera glycines. (Abstr.) Phytopathology 83:467.

27. Roy, K. W., Lawrence, G. W., Hodges, H. H. McLean, K. S., and Killebrew, J. F. 1988. Etiology of sudden death syndrome of soybean. Proc. South. Soybean Dis. Workers Conf. 15:30.

28. Roy, K. W., Lawrence, G. W., Hodges, H. H. McLean, K. S., and Killebrew, J. F. 1989. Sudden death syndrome of soybean: Fusarium solani as incitant and relation of Heterodera glycines to disease severity. Phytopathology 79:191-197.

29. Roy, K. W., Lawrence, G. W., and McLean, K. S. 1989. Isolation and identification of Fusarium solani, the cause of sudden death syndrome of soybean. Plant Diagn. Quart. 10:17-27

30. Roy, K. W., Lawrence, G. W., McLean, K. S. Hodges, H. H., and Hirrel, M. C. 1989. Sudden death syndrome of soybean: The causal agent. Pages 1290-1295 in: Proc. World Soybean Res. Conf. IV, Buenos Aires, Argentina. A. J. Pascale, ed. Westview Press, Boulder, CO.

31. Roy, K. W., Moore, W. F., and Abney, T. S. 1991. Diagnosis of sudden death syndrome of soybean. Plant Diagn. Quart. 12:166-168.

32. Roy, K. W., and Ratnayake, S. 1996. Asexual reproduction and survival of Fusarium solani in soybean fields. (Abstr.) Phytopathology 86:97.

33. Roy, K. W., and Van Etten, H. 1993. Further characterization of Fusarium solani strains from soybean. Int. Congr. Plant Pathol., 6th. p. 143.

34. Rupe, J. C. 1989. Frequency and pathogenicity of Fusarium solani recovered from soybeans with sudden death syndrome. Plant Dis. 73:581-584.

35. Rupe, J. C., and Becton, C. M. 1992. Vertical distribution of Fusarium solani, causal agent of sudden death syndrome of soybean, in two fields. (Abstr.) Phytopathology 82:1134.

36. Rupe, J. C., Becton, C. M., Williams, K. J. and Yount, P. 1996. Isolation, identification, and evaluation of fungi for the control of sudden death syndrome of soybean. Can. J. Plant Pathol. 18:1-6.

37. Sciumbato, G. L., and Keeling, B. L. 1985. Sudden death syndrome of soybeans in Mississippi in 1984. Proc. South. Soybean Dis. Workers Conf. 12:64

38. Sinclair, J. B., and Backman, P. A., eds. 1989 Compendium of Soybean Diseases. 3rd ed American Phytopathological Society, St. Paul, $\mathrm{MN}$.

39. Steel, R. G. D., and Torrie, J. H. 1960. Principles and Procedures of Statistics. McGrawHill, New York.

40. Trujillo, E. E. 1969. Relationship of crop residues to increased persistence and inoculum density of soil-borne pathogens. Pages 23-26 in: Nature of the Influence of Crop Residues on Fungus-Induced Root Diseases. R. J. Cook and R. D. Watson, eds. Wash. Agric. Exp. Stn. Bull. 716

41. von Qualen, R. H., Abney, T. S., Huber, D. M., and Schreiber, M. M. 1989. Effects of rotation, tillage, and fumigation on premature dying of soybeans. Plant Dis. 73:740-744.

42. Yang, S. M., and Hagedorn, D. J. 1967. Cultural and pathogenicity studies of induced variants of bean and pea root rot Fusarium species. Phytopathology 58:639-643.

43. Yang, X. B., and Rizvi, S. S. A. 1994. First report of sudden death syndrome of soybean in Iowa. Plant Dis. 78:830. 